\title{
Effects of Pretreatment on the Removal of COD from Brewery Wastewater
}

\author{
E. Fosso-Kankeu, O.T.G. Lunga, D. Moyakhe, F.B. Waanders and C de Klerk
}

\begin{abstract}
This research study focuses on the brewing industry for it constitutes an important economic segment of any country in the world. The effluents from brewering processes such as fermentation and filtering contain high organics/biochemical oxygen demand (BOD). The study investigates the effect of pre-treatment on the performance of coagulants/flocculants used for the removal of organic matters [chemical oxygen demand (COD)] in the brewery effluents. Different types of flocculants and coagulants were used to assess their effectiveness in the treatment of different samples with various $\mathrm{pH}$ due to the type of pretreatment. The optimum dosages of the coagulants and flocculants were assessed. Their performance on the removal of COD was assessed individually and in combinations to find the best combination for the removal of the COD. The results showed that coagulants/flocculants performed well at $\mathrm{pH} 5$ and optimum dosages were identified for the reduction of COD to acceptable level in all brewery effluents.
\end{abstract}

Keywords - Carbon Oxygen demand, Coagulation and flocculation performance, Optimum dosage, pretreatment.

\section{INTRODUCTION}

The accessibility to usable fresh water is a worldwide concern because of both limited water resources and a steadily growing population. In manufacturing industries in many countries including South Africa, there are large volumes of polluting effluents discharged yearly into inland waterways [1-24]. This research study focuses on the brewing industry for it constitutes an important economic segment of any country in the world. The production of beer on a commercial scale requires much more water than just what is contained in the beer itself if one takes into account the water used for cooling and hygienic purposes [25].

The wastewater effluent and solid waste from beer production, is supposed to be disposed of or treated in the least costly and safest way. Numerous breweries worldwide are searching for means to cut down on water usage during the beer brewing process [26]. Some are also investigating ways to cost

E. Fosso-Kankeu is with the Water Pollution Monitoring and Remediation Initiatives Research Group in the School of Chemical and Minerals Engineering of the North West University, South Africa.

F. Waanders is with the Water Pollution Monitoring and Remediation Initiatives Research Group in the School of Chemical and Minerals Engineering of the North West University, South Africa.

O.T.G. Lunga is with the Water Pollution Monitoring and Remediation Initiatives Research Group in the School of Chemical and Minerals Engineering of the North West University, Potchefstroom-South Africa.

Corli De Klerk is with the Department of Quality Control, United National Breweries, South Africa.

Dumisane Moyakhe is with the Water Pollution Monitoring and Remediation Initiatives Research Group in the School of Chemical and Minerals Engineering of the North West University, South Africa effectively and safely treat the brewery wastewater for reuse. The large volumes of water used during beer brewing results in the brewery industry discharging large volumes of highly polluting effluents thus the disposal of untreated brewery wastewater into water bodies can constitute potential or severe pollution to the water bodies [27]. The aim of the investigation is to determine the effect of pre-treatment on the performance of flocculants during chemical oxygen demand (COD) removal. COD is a measure of the oxygen equivalent of the organic matter content of a sample that is susceptible to oxidation by a strong oxidant [28]. Brewery wastewater typically has a high chemical oxygen demand (COD) from all the organic components (sugars, soluble starch, ethanol, and volatile fatty acids), etc. The $\mathrm{pH}$ levels can range between 2 and 12 and are influenced by the amount and type of chemicals used in cleaning and sanitizing [29,30]. Pre-treatment is meant to alter the physical, chemical, and/or biological properties of feed water, thus improving the performance of downstream processes. This study is meant to show if these pre-treatment process, limit or affect the performance of coagulants/flocculants during the removal of COD. If the performance of coagulants/flocculants is hindered it could result in the removal of COD being less effective increasing costs of the treatment of the brewery wastewater or making the waste water treatment plants less effective.

\section{Flocculation and coagulation}

Flocculation and Coagulation are very important procedures in wastewater treatment. A fundamental element of wastewater flocculation is the removal of suspended solids and most of the organic substances as much as possible. Coagulation is the process where the destabilization of a given suspension or solution is affected [31-48]. That is, the function of coagulation is to overcome those factors which promote the stability of a given system. Flocculation is the process whereby destabilized particles, or particles formed as a result of destabilization, are induced to come together, make contact and thereby form large(r) agglomerates [31]. All the solid material in a fluid medium have some kind of property that is related with interfacial experiences. These interfacial experiences incorporate the impacts of the surface charge conveyed by particles and the level of solvation of the colloid surface layers. Stability with the colloids is the ability for the colloids to keep a dispersed state that is the ability for the individual colloids to remain separate entities [31]. With decreasing effective particle size, the effective surface area of the particle turns out to be 
enormous for a given all particle mass. Subsequently, it becomes evident that for small mass particle, interfacial surface effects dominate with the lesser from gravitational impacts related with mass of the particle. Particles in the colloidal size range, with hydrodynamic impacts alone, settling times of as long as several years are required. Methods other than Gravity are used to destabilize the solution which is flocculation and coagulation [49].

\section{EXPERIMENTAL STUDY}

Investigation of the effect of pretreatment on the removal of COD from Brewery Wastewater was carried out using samples from the brewery; this was achieved through optimization of coagulants and flocculants dosages and types.

\section{A. Sample collection \& characterization}

Samples were collected using two, 25 liter containers which were then transported to the laboratory for analysis. Three sets of samples of different $\mathrm{pH}$ values had to be obtained. The samples include, normal brewery discharge at $\mathrm{pH} 7-8$, discharge at $(\mathrm{pH} 4-6$, discharge at $\mathrm{pH} 10-13$. Experiments had to be carried out within 3 days to avoid change in the sample quality. The COD, hydrogen ion concentration, Turbidity and the zeta potential were measured as the characterization parameters considered. The turbidity of the Sample was measured four times with the average taken as the final value with a turbidometer.

\section{B. Flocculation and coagulation}

The coagulants used in the study were ferric chloride and an organic coagulant mixture in aqueous solution (brewery coagulant). The flocculants were a cationic flocculant (Genesys' genefloc, polyquaternary amine), an anionic flocculant (Senfloc 5210), a non-ionic flocculant (Senfloc 5330) and a cationic acrylamide copolymer in aqueous dispersion (Himoloc TG823) obtained from the brewery. The procedures for the preparation of ferric chloride, Senfloc 5210, Senfloc 5330 and Genesys' genefloc, polyquaternary amine solution were similar. A clean watch glass was tared on a scale with $1 \mathrm{~g}$ of each substance measured and dissolved in $1 \mathrm{~L}$ volumetric flasks making a $1000 \mathrm{ppm}$ solution. For every $5 \mathrm{~mL}$ pipetted to the beaker, $10 \mathrm{ppm}$ was made up in the $500 \mathrm{~mL}$ beaker. The Brewery Flocculent and the Coagulant were in dispensation. The solutions were made by measuring $1 \mathrm{~mL}$ of the substance and making it up to $1 \mathrm{~L}$ (1000 ppm solution). For every $5 \mathrm{~mL}$ pipetted to the beaker, $10 \mathrm{ppm}$ was made up in the $500 \mathrm{~mL}$ beaker.

\section{Jar test procedure}

The jar test mixer was used to carry out the experiments. Six 1 liter beakers were used to carry out the jar test for a single run. The Beakers used were filled up to $500 \mathrm{~mL}$ for all runs. The jar tests for the coagulants were done by adding the coagulant and mixing rapidly at $200 \mathrm{rpm}$ for 2 minutes (rapid mixing) with the slow mixing at $40 \mathrm{rpm}$ for 15 minutes. The jar tests involving both the coagulants and the flocculants were done by adding the coagulant and mixing at $200 \mathrm{rpm}$ for 2 minutes and during the slow mixing, the flocculant was added at $40 \mathrm{rpm}$ for 15 minutes. The settling time for all mixtures was 1 hour.
The first procedure in the experiment was to find the optimum dosage for the coagulant. The optimum dosage was determined by first taking a wide dosage range (run 1 and run 2) of $10 \mathrm{ppm}, 20 \mathrm{ppm}, 40 \mathrm{ppm}, 80 \mathrm{ppm}, 100 \mathrm{ppm}$ and $120 \mathrm{ppm}$; then after the jar test, the turbidity of the solution was taken. By looking at the results of run 1 and run 2, dosages with high turbidity results were disregarded and a new dosage range determined (zoom). Results of the zoom were used to find the final dosage range. Final dosage values (final zoom) were determined from values obtained from zoom. The optimum dosage had the lowest value of turbidity in the zoom-in run.

\section{E. Flocculent optimization}

After obtaining the optimum dosage range for the coagulants, the values of the optimum coagulant dosages were used to optimize the flocculants. The flocculents dosages range of $5 \mathrm{ppm}, 10 \mathrm{ppm}, 20 \mathrm{ppm}, 30 \mathrm{ppm}, 40 \mathrm{ppm}$ and $50 \mathrm{ppm}$ was utilized to determine the optimum flocculent dosage. This was carried out for all the flocculants with the different optimum dosage values of the coagulants.

\section{RESULTS}

\section{A. Brewery Wastewater Characterization}

The study focused of 3 different samples with different $\mathrm{pH}$ values. The characterization parameters measured for the samples were the COD, Turbidity, PH and the Zeta potential. Table 1 shows the results of the characterization of the samples.

TABLE I_CHARACTERIZATION OF BREWERY WASTEWATER SAMPLES
\begin{tabular}{|c|c|c|c|c|}
\hline Sample & $\mathbf{1}$ & $\mathbf{2}$ & $\mathbf{3}$ & Units \\
\hline pH & 5.12 & 7.86 & 12.84 & - \\
\hline COD & 10524.7 & 3493 & 2293.5 & $\mathrm{mg} / 1$ \\
\hline $\begin{array}{c}\text { Zeta } \\
\text { potential }\end{array}$ & -3.32 & -7.69 & -19.25 & $\mathrm{mV}$ \\
\hline Turbidity & 1829 & 464.25 & 609.7 & NTU \\
\hline
\end{tabular}

The Zeta potential of the sample was negative for all the samples due to the ionization of anionic functional groups of phosphate and carboxylic functional groups that give a net negative charge to Extracellular Polymeric Substances and microbial cells. The $\mathrm{pH}$ of the wastewater varies across samples. Sample 1 has a low $\mathrm{pH}$ because, when live fermenting sorghum of the beer at shops is unsold after a long time, the unsold products are sent back to the brewery for disposal which produces the low $\mathrm{pH}$ effluent with very high turbidity and COD values. Sample 2 is normal brewery effluent which is set to have a $\mathrm{pH}$ of 7,8 . It has a much lower $\mathrm{COD}$ and turbidity value because it is first filtered then disposed of. Sample 3 has a much higher $\mathrm{pH}$ because this it derives from the wash of CIP (cleaning in progress). The brewery cleans their machinery with basic cleaners (Sodium Hydroxide) which gives the effluent a very high $\mathrm{pH}$ and lower turbidity and COD values.

\section{Optimizing Coagulants-Ferric Chloride \& Brewery coagulant}

Table 2 shows the optimum coagulant dosage for the different samples after several jar test procedures.

\section{Coagulant Optimization}




\begin{tabular}{|l|c|c|c|c|}
\hline Coagulant & Sample 1 & Sample 2 & Sample 3 & Units \\
\hline Ferric & 125 & 87.5 & 85 & $\mathrm{ppm}$ \\
\hline Brewery & 140 & 77.5 & 103 & $\mathrm{ppm}$ \\
\hline
\end{tabular}

\section{Brewery Wastewater Optimum Flocculent Dosages}

The optimization of flocculants was done using four flocculent with 3 different charges namely cationic flocculants (Genesys' genefloc, polyquaternary amine), an anionic flocculent (Senfloc 5210), a non-ionic flocculants (Senfloc 5330) and a cationic acrylamide copolymer in aqueous dispersion (Himoloc TG823). The Flocculent dosages were constant through the optimum coagulant dosage determination and it was done for all three samples with the two coagulants at their optimum dosages. The optimum flocculant dosages are shown in Table 5.

\section{COD Removal efficiency}

After the determination of the optimum flocculent dosage, the samples were collected and the COD values of the samples were recorded. The COD efficiency was calculated using Equation 1. The higher the COD efficiency the better the performance.

$$
\text { COD removal efficiency }=\frac{E_{f}-E_{i}}{E_{f}} \times 100 \%
$$

\section{Where}

$E_{f}$ Is the final COD value measured after flocculant optimization.

$E_{i}$ Is the initial COD value measured from the sample.

\section{Effect of pH on the performance Coagulants}

The effect of $\mathrm{pH}$ on the coagulants will be analyzed using the turbidity values measured. The quantity of suspended particles (expressed as turbidity) removed per quantity of coagulant used will be assessed to see if the $\mathrm{pH}$ affects the performance of coagulant. The results of the final zoom will be used for this analysis, as the values are around the optimum dosage. Table 3 summarizes the performance at different $\mathrm{pH}$ values of the ferric chloride and Table 4 summarizes the performance of the brewery coagulant.

TABLE III-PERFORMANCE ANALYSIS OF FERRIC CHLORIDE

\begin{tabular}{|c|c|c|c|}
\hline Sample & 1 & 2 & 3 \\
\hline $\mathrm{pH}$ & 5.12 & 7.86 & 12.84 \\
\hline $\begin{array}{c}\text { Turbidity } \\
\text { removal per } \\
\text { Dosage of } \\
\text { Coagulant } \\
\text { NTU/ppm }\end{array}$ & 14.08 & 4.92 & 5.51 \\
\hline
\end{tabular}

TABLE IV-PERFOMANCE OF BREWERY COAGULANT

\begin{tabular}{|c|c|c|c|}
\hline Sample & 1 & 2 & 3 \\
\hline $\mathrm{pH}$ & 5.12 & 7.86 & 12.84 \\
\hline $\begin{array}{c}\text { Turbidity } \\
\text { removal per } \\
\text { Dosage of } \\
\text { Coagulant } \\
\text { NTU/ppm }\end{array}$ & 12.98 & 6.14 & 5.91 \\
\hline
\end{tabular}

The coagulants both performed very well in removing turbid material at a $\mathrm{pH}$ of 5 . This could be attributed to the coagulants operating at their optimum $\mathrm{pH}$ range. The ferric chloride performed better than the brewery coagulant with sample 1 . With Sample 2, the brewery coagulant performed better than the ferric chloride and Sample 3 had the brewery coagulant performing slightly better than the ferric chloride. There is a difference in the performance of the coagulant across the range of $\mathrm{pH}$ values with both coagulants performing very well in acidic conditions with performance generally decreasing for the brewery coagulant as the $\mathrm{pH}$ values increase. The ferric chloride has its lowest performance at the more neutral $\mathrm{pH}$ of sample 2 .

\section{Effect of $\mathrm{pH}$ on the performance of the combined Flocculants and coagulants}

The performance of the combination of the flocculants and coagulants is shown in Table 5. The COD removal efficiency is a measure of how much a part per million of coagulant removes COD from the sample. With sample 1, the ferric Chloride combination performed better than the brewery coagulant combination as the ferric chloride slightly removed more COD than the Brewery coagulant combinations. Ferric chloride combination outperforming the brewery coagulant combinations could be due to the fact that ferric chloride is at its optimum $\mathrm{pH}$. The combination that removed the most COD was the combination of the ferric chloride and the non-ionic flocculant in Sample 1. With Sample 2, the best performing combination was the brewery coagulant and the cationic flocculant and with sample 3 the best performing combination was the brewery coagulant and the cationic flocculant. The $\mathrm{pH}$ of the samples affects the performance of the flocculant and coagulant combined, the best performance was recorded at the $\mathrm{pH}$ of Sample 1 (low $\mathrm{pH}$ ) with the performance decreasing as the $\mathrm{pH}$ of the samples increased.

\section{CONCLUSION}

The amount of brewery effluent discharged from the brewery still constitutes a problem for both the municipality and the environment. Generally, the brewery wastewater effluents are a worldwide problem, and ways to recycle these brewery wastewaters will help reduce the concerns that are associated with the disposal of the brewery effluent to the environment and will reduce the amount of fresh water consumed in the brewery process. Wastewater purification/treatment before disposal is the method considered to help reduce environmental impacts of disposal by the brewery. This does not help in reduction of water consumption by the brewery but helps reduce the impact of brewery wastewater to the environment. 
This is a solution considered to conform to the government's legislation regarding discharge of brewery effluents. The results obtained in this study may assist on how to handle different brewery effluents at different $\mathrm{pH}$ values for the brewery effluents and also for breweries of same wastewater characteristics. The effect of the effluents $\mathrm{pH}$ on the performance of the coagulants was assessed considering the amount COD removed by a part per million of a coagulant.It was observed that the performance of coagulants reduces as the $\mathrm{pH}$ values increased. This is shown in Table 5 were the COD removal efficiency values decrease as the $\mathrm{pH}$ values increase. This is not clear in Table 3, where Sample 2 has the lowest removal efficiency. In Table 4, the trend of the performance decreasing as $\mathrm{pH}$ values increase could also be observed. For both evaluation, the ferric chloride performed the best at a $\mathrm{pH}$ of 5-6 most probably attributed by the Ferric Chloride operating at optimum $\mathrm{pH}$ conditions.

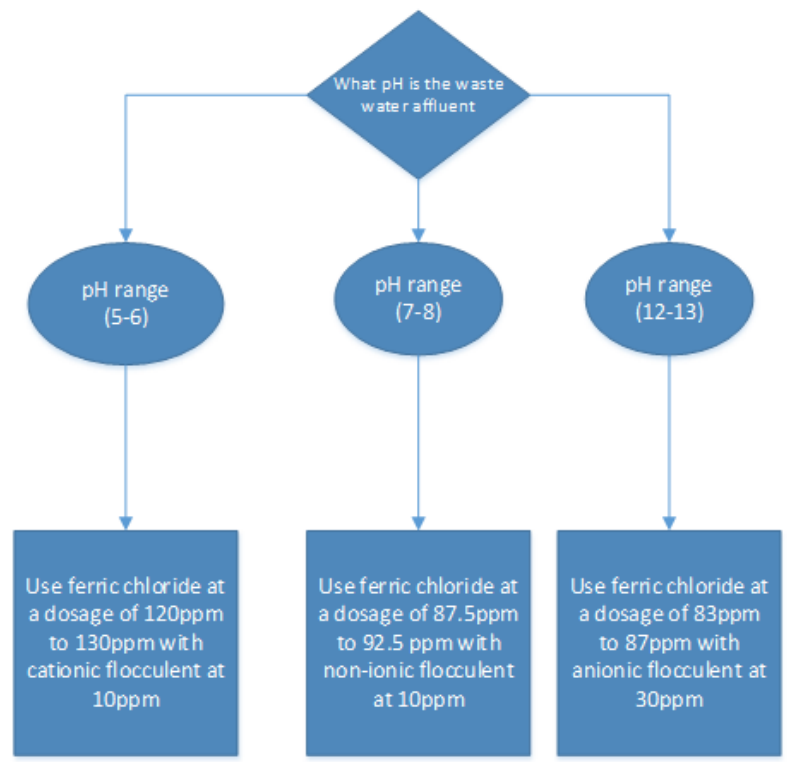

Fig. 1-Recommended dosages for specific $\mathrm{pH}$ values

TABLE V - OPTIMUM FLOCCULANT DOSAGES AND THE COD EFFICIENCY VALUES

\begin{tabular}{|l|l|l|l|l|l|l|l|}
\hline Coagualant & Floculant & $\begin{array}{c}\text { Optimum } \\
\text { flocculant } \\
\text { Dosage } \\
\text { Sample 1 }\end{array}$ & $\begin{array}{l}\text { COD } \\
\text { Removal } \\
\text { Efficiency - } \\
\text { mg COD per } \\
\text { ppm } \\
\text { coagulant }\end{array}$ & $\begin{array}{l}\text { Optimum } \\
\text { flocculant } \\
\text { Dosage } \\
\text { Sample 2 }\end{array}$ & $\begin{array}{l}\text { COD } \\
\text { Removal } \\
\text { Efficiency } \\
\text {-mg COD } \\
\text { per ppm } \\
\text { coagulant }\end{array}$ & $\begin{array}{l}\text { Optimum } \\
\text { flocculant } \\
\text { Dosage } \\
\text { Sample 3 }\end{array}$ & $\begin{array}{l}\text { COD } \\
\text { Removal } \\
\text { Efficiency } \\
\text {-mg COD } \\
\text { per ppm } \\
\text { coagulant }\end{array}$ \\
\hline Ferric & Anionic & 5 & 38.12 & 10 & 27.80 & 30 & 14.69 \\
\hline Ferric & Cationic & 40 & 36.36 & 40 & 27.75 & 20 & 11.08 \\
\hline Ferric & non-ionic & 10 & $\mathbf{3 9 . 6 6}$ & 10 & 26.54 & 40 & 4.66 \\
\hline Ferric & Brewery & 10 & 39.55 & 10 & 27.55 & 40 & 11.77 \\
\hline Brewery & Anionic & 30 & 35.61 & 20 & 17.39 & 20 & 10.43 \\
\hline Brewery & Cationic & 10 & 37.63 & 5 & $\mathbf{3 5 . 1 2}$ & 5 & $\mathbf{1 3 . 7 0}$ \\
\hline Brewery & non-ionic & 50 & 37.43 & 5 & 28.97 & 50 & 10.78 \\
\hline Brewery & Brewery & 10 & 37.48 & 5 & 29.15 & 40 & 10.40 \\
\hline
\end{tabular}




\section{ACKOWLEDGEMENT}

The authors are thankful to the support from the North-West University. The authors also appreciate the assistance of $\mathrm{Mr} \mathrm{N}$ Lemmer.

\section{REFERENCES}

[1] Fillaudeau, L.; Blanpain-Avet, P.; Daufin, G. 2006. Water, wastewater and waste management in brewing industries, Journal of Cleaner Production 14:463-471. https://doi.org/10.1016/j.jclepro.2005.01.002

[2] Elvis Fosso-Kankeu. 2019. Nano and Bio-based Technologies for wastewater treatment: Prediction and Control Tools for the dispersion of Pollutants in the Environment. Wiley Scrivener. ISBN: 978-1-119-57709-6. Pp 301-336.

[3] Elvis Fosso-Kankeu. 2019. New Horizons in Wastewaters Management: Emerging Monitoring and Remediation Strategies. Nova Science Publishers. ISBN: 978-1-53615-659-1.

[4] Nthambeleni Mukwevho, Elvis Fosso-Kankeu, Frans Waanders, Neeraj Kumar, Suprakas Sinha Ray, Xavier Yangkou Mbianda. 2019. Evaluation of the photocatalytic activity of $\mathrm{Gd}_{2} \mathrm{O}_{2} \mathrm{CO}_{3} \cdot \mathrm{ZnO} \cdot \mathrm{CuO}$ nanocomposite used for the degradation of phenanthrene. Springer Nature Applied Sciences. https://doi.org/10.1007/s42452-018-0012-0. 1-10.

[5] Fosso-Kankeu E., Potgieter J. and Waanders F.B. 2019. Removal of malachite green and toluidine blue dyes from aqueous solution using a clay-biochar composite of bentonite and sweet sorghum bagasse. International Journal of Applied Engineering Research. 14(6): 1324-1333.

[6] Kolela J Nyembwe, Elvis Fosso-Kankeu, Frans Waanders, Kasongo D Nyembwe. 2019. Structural, compositional and mineralogical characterisation of carbonatitic copper sulfide concentrator plant streams: Run of mine, concentrate and tailings. International Journal of Minerals, Metallurgy and Materials. 26(2): 143-151. https://doi.org/10.1007/s12613-019-1718-8

[7] Johannes Cornelius van der Linde, Elvis Fosso-Kankeu, Gerhard Gericke, Frans Waanders, Louise Dreyer, Nico Lemmer. 2019. Flocculant types and operating conditions influencing particles settling rates in feed water used at a coal power plant. Desalination and Water Treatment. 150: 293-300.

https://doi.org/10.5004/dwt.2019.23735

[8] Assumpta Chinwe Nwanya, Miranda M. Ndipingwi, Noluthando Mayedwaa, LC Razanamahandry, Chinwe O Ikpo, Tesfaye Waryo, SKO Ntwampe, E Malenga, E Fosso-Kankeu, Fabian I Ezema, Emmanuel I Iwuoha, Malik Maaza. 2019. Maize (Zea mays L.) fresh husk mediated biosynthesis of copper oxides: Potentials for pseudo capacitive energy storage. Electrochimica Acta. 301: 436-448. https://doi.org/10.1016/j.electacta.2019.01.186

[9] LC Razanamahandry, CT Onwordi, W Saban, AKH Bashir, L Mekuto, E Malenga, E Manikandan, E Fosso-Kankeu, M Maaza, SKO Ntwampe. 2019. Performance of various cyanide degrading bacteria on the biodegradation of free cyanide in water. Journal of Hazardous Materials. 380: $1-6$. https://doi.org/10.1016/j.jhazmat.2019.120900

[10] IG Erdogan, L Mekuto, SKO Ntwampe, E Fosso-Kankeu, FB Waanders. 2019. Metagenomic profiling dataset of bacterial communities of a drinking water supply system (DWSS) in the arid Namaqualand region, South Africa: Source (lower Orange River) to point-of-use (O'kiep). Journal of Data in Brief. 25: 104135-104140.

https://doi.org/10.1016/j.dib.2019.104135

[11] N Kumar, E Fosso-Kankeu, SS Ray. 2019. Achieving controllable MoS2 nanostructures with increased interlayer spacing for efficient removal of $\mathrm{Pb}$ (II) from aquatic systems. ACS Applied Materials and Interfaces. 11: 19141-19155. https://doi.org/10.1021/acsami.9b03853

[12] N Mukwevho, N Kumar, E Fosso-Kankeu, F Waanders, J Bunt, SS Ray. 2019. Visible light-excitable $\mathrm{ZnO} / 2 \mathrm{D}$ graphitic-C3N4 heterostructure for the photodegradation of naphthalene. Desalination and Water Treatment. 163: 286-296. https://doi.org/10.5004/dwt.2019.24422

[13] E Fosso-Kankeu, R Weideman, D Moyakhe, FB Waanders, M Le Roux, QP Campbell. 2019. Hydrothermal preparation of biochar from spent coffee grounds, and its application for the removal of cadmium from coal tailings leachate. The Journal of the Southern African Institute of Mining and Metallurgy. 119: 607-612. https://doi.org/10.17159/2411-9717/449/2019

[14] R Gusain, N Kumar, E Fosso-Kankeu, SS Ray. 2019. Efficient removal of $\mathrm{Pb}$ (II) and $\mathrm{Cd}$ (II) from industrial mine water by a hierarchical MoS2/SH-MWCNT nanocomposite. ACS Omega. 4: 13922-13935. https://doi.org/10.1021/acsomega.9b01603

[15] Nthambeleni Mukwevho, Rashi Gusain, Elvis Fosso-Kankeu, Neeraj Kumar, Frans Waanders, Suprakas Sinha Ray. 2019. Removal of naphthalene from simulated wastewater through adsorption-photodegradation by $\mathrm{ZnO} / \mathrm{Ag} / \mathrm{GO}$ nanocomposite. Journal of Industrial and Engineering Chemistry. https://doi.org/10.1016/j.jiec.2019.09.030

[16] Erdogan IC, Fosso-Kankeu E, Ntwampe SKO, Waanders FB, Hoth N, Rand A, Farrar TJ. 2019. Households water quality in O'kiep - South Africa and community perception of related health risks. 167(2019): 145-155. https://doi.org/10.5004/dwt.2019.24576

[17] Soumasree Chatterjee, Soumya Pandit, Elvis Fosso-Kankeu. 2019. Removal of heavy metal pollutants from wastewater using immobilized enzyme techniques: A review. In Nano and Bio-based Technologies for wastewater treatment: Prediction and Control Tools for the dispersion of Pollutants in the Environment. Editor: Elvis Fosso-Kankeu. Wiley Scrivener. ISBN: 978-1-119-57709-6. Pp 457-478.

[18] Namita Khanna, Akshayaa Sridhar, Ramachandran Subramanian, Soumya Pandit, Elvis Fosso-kankeu. 2019. Phycoremediation: A Solar Driven Wastewater Purification System. In Nano and Bio-based Technologies for wastewater treatment: Prediction and Control Tools for the dispersion of Pollutants in the Environment. Editor: Elvis Fosso-Kankeu. Wiley Scrivener. ISBN: 978-1-119-57709-6. Pp 371-426.

[19] Sadanand Pandey, Gopal Krishna Goswami, Hussein Kehinde Okoro, Elvis Fosso-Kankeu. 2019.Carbon nanotubes in the 21st Century: An Advancement in real time monitoring and control of environmental water. In Nano and Bio-based Technologies for wastewater treatment: Prediction and Control Tools for the dispersion of Pollutants in the Environment. Editor: Elvis Fosso-Kankeu. Wiley Scrivener. ISBN: 978-1-119-57709-6. Pp 263-300.

[20] Sajana T.K, Soumya Pandit, Dipak A. Jadhav, Md. Abdullah-Al-Mamun, Elvis Fosso-Kankeu. 2019. Sediment Microbial Fuel Cell for Wastewater Treatment: A New Approach. In Nano and Bio Based Technologies for wastewater treatment: Prediction and Control Tools for the dispersion of Pollutants in the Environment. Editor: Elvis Fosso-Kankeu. Wiley Scrivener. ISBN: 978-1-119-57709-6. Pp 301-336.

[21] J.G. Redelinghuys, E. Fosso-Kankeu, G. Gericke, F. Waanders. 2019. Coal Power Plant Wastewater Treatment by Thermal and Membrane Technologies. In Nano and Bio-based Technologies for wastewater treatment: Prediction and Control Tools for the dispersion of Pollutants in the Environment. Editor: Elvis Fosso-Kankeu. Wiley Scrivener. ISBN: 978-1-119-57709-6. Pp 149-168. https://doi.org/10.1002/9781119577119.ch5

[22] N. Mukwevho, E. Fosso-Kankeu, F. Waanders. 2019. PAHs Released from Coal Tars and Potential Removal Using Nanocatalysts. In Nano and Bio-based Technologies for wastewater treatment: Prediction and Control Tools for the dispersion of Pollutants in the Environment. Editor: Elvis Fosso-Kankeu. Wiley Scrivener. ISBN: 978-1-119-57709-6. Pp 169-203. https://doi.org/10.1002/9781119577119.ch6

[23] Enoch A. Akinpelu, Elvis Fosso-Kankeu, Seteno K.O. Ntwampe, Frans Waander. 2019. Stoichiometric and thermodynamic analysis: implications in bioremediation. In New Horizons in Wastewaters Management: Emerging Monitoring and Remediation Strategies. Editor: Elvis Fosso-Kankeu. Nova Science Publishers. ISBN: 978-1-53615-659-1.

[24] Corli de Klerk,Elvis Fosso-Kankeu and Frans Waanders. 2019. Nanoparticle-biopolymer antimicrobial compounds as sustainable option for wastewater treatment. In New Horizons in Wastewaters Management: Emerging Monitoring and Remediation Strategies. Editor: Elvis Fosso-Kankeu. Nova Science Publishers. ISBN: 978-1-53615-659-1.

[25] Parawira, W.; Kudita, I.; Nyandoroh, M.G. 2005. A Study of industrial anaerobic treatment of opaque beer brewery wastewater in a tropical climate using a full-scale UASB reactor seeded with activated sludge, Process Biochemistry 40 (2) 593-599. 
https://doi.org/10.1016/j.procbio.2004.01.036

[26] Geoffrey S. Simate a, G. S., 2011. Desalination. The treatment of brewer wastewater for reuse: State of the art, 1-20.

[27] Braeken, L.; Van der Bruggen, B.; Vandecasteele, C. 2004. Regeneration of brewery waste water using Nano filtration, Water Research, 38 (13) 3075-3082. https://doi.org/10.1016/j.watres.2004.03.028

[28] Simate GS, Cluett J, Iyuke SE, Musapatika ET, Ndlovu S, Walubita LF. The treatment of brewery wastewater for reuse: State of the art. Desalination. 2011; 273(2-3):235-247. http://dx.doi.org/10.1016/j.desal.2011.02.035.

[29] T Adesoji., K Jaiyeola Joseph., U.E. Inyang., E.N. Bassey and J.D. Inyang., Characterisation of Brewery Wastewater Effluent, 2012, (67-68).

[30] Driessen, W., Vereijken, T., Recent developments in biological treatment of brewery effluent. The Institute and Guild of Brewing Convention; 2003:10.

[31] Pillai, J. \& Nalco Company. 1997. Flocculants and Coagulants: The Keys to Water and Waste Management in Aggregate Production, Stone Review: 1-6.

[32] E. Fosso-Kankeu; O. Ntwampe, F. Waanders, and A. Webster, The Performance of Polyaluminium Chloride and Bentonite clay Coagulant in the Removal of Cationic and Anionic Dyes. $7^{\text {th }}$ International Conference on Latest Trends in Engineering and Technology (ICLTET' 2015), November 26-27, 2015 Irene, Pretoria (South Africa). Editors: E. Muzenda and T Yingthawornsuk. ISBN: 978-93-84422-58-5. 2015.

[33] E. Fosso-Kankeu, F. Waanders, R. Swiegers, I.O. Ntwampe, D. Rogers, G. Gericke, Impact of the physico-chemical properties of water on the flocculation performance of lime, clay and other polymers. International Conference on Advances in Science, Engineering, Technology and Natural Resources (ICASETNR-16) Nov. 24-25, 2016, Parys - South Africa. ISBN: 978-93-84468-79-8. 2016.

[34] E. Fosso-Kankeu, F.B. Waanders, G. Gericke, N. Lemmer, L.M. Dreyer and $\mathrm{J}$. van der Linde, Investigation of the potential of monomeric and polymeric coagulants in the treatment of raw water used at a coal-fired power station. $9^{\text {th }}$ Int'l Conference on Advances in Science, Engineering, Technology \& Waste Management (ASETWM-17). 27-28 November 2017, Parys, South Africa. Editors: F. Waanders, E. Fosso-Kankeu, B. Topcuoglu, M. Plaisent, Y. Thaweesak. ISBN: 978-81-934174-6-1. Pp. 44-48. 2017.

[35] D.M. Moyakhe, Q.P. Campbell, E. Fosso-Kankeu, The effect of flocculant type on settling properties of fine coal tailings. $9^{\text {th }}$ Int'l Conference on Advances in Science, Engineering, Technology \& Waste Management (ASETWM-17). 27-28 November 2017, Parys, South Africa. Editors: F. Waanders, E. Fosso-Kankeu, B. Topcuoglu, M. Plaisent, Y. Thaweesak. ISBN: 978-81-934174-6-1. Pp. 165-168. 2017.

[36] J.C. van der Linde, E. Fosso-Kankeu, G. Gericke, N. Lemmer, and F. Waanders, Removal of Total Hardness and Alkalinity from RO - reject water. $9^{\text {th }}$ Int'l Conference on Advances in Science, Engineering, Technology \& Waste Management (ASETWM-17). 27-28 November 2017, Parys, South Africa. Editors: F. Waanders, E. Fosso-Kankeu, B. Topcuoglu, M. Plaisent, Y. Thaweesak. ISBN: 978-81-934174-6-1. Pp. 147-151. 2017

[37] Elvis Fosso-Kankeu, Christiaan Steyn van der Vyver, Corli de Klerk, Dumisane Moyakhe and Frans Waanders. 2018. Brewery effluent sludge characterization and dewatering to increase potential water recycling capabilities. Editors: Elvis Fosso-Kankeu, Frans Waansders, Michel Plaisent. 10th Int'l Conference on Advances in Science, Engineering, Technology \& Healthcare (ASETH-18) Nov. 19-20, 2018 Cape Town (South Africa). ISBN: 978-81-938365-2-1. Vol I. Pp 106-114.

[38] JC van der Linde, E Fosso-Kankeu, G Gericke, F Waanders and T. Tamane. 2018. Effect of Temperature on the Performance of Rheofloc: Conductivity Removal from RO-reject. Editors: Elvis Fosso-Kankeu, Frans Waansders, Michel Plaisent. 10th Int'l Conference on Advances in Science, Engineering, Technology \& Healthcare (ASETH-18) Nov. 19-20, 2018 Cape Town (South Africa). ISBN: 978-81-938365-2-1. Vol II. Pp 139-143.

[39] E. Fosso-Kankeu, L. Van Schalkwyk, J. Van Der Linde, G. Gericke and F.B. Waanders. 2018. Pretreatment of Coal Power Plant RO Retentate using AR Floc 100. Editors: Elvis Fosso-Kankeu, Frans Waansders, Michel Plaisent. 10th Int'l Conference on Advances in Science, Engineering, Technology \& Healthcare (ASETH-18) Nov. 19-20, 2018 Cape Town (South Africa). ISBN: 978-81-938365-2-1. Vol II. Pp 149-154.
[40] I.O. Ntwampe, F.B. Waanders, E. Fosso-Kankeu and J.R. Bunt, Turbidity removal efficiency of clay and a synthetic af-PFCl Polymer of Magnesium Hydroxide in AMD Treatment. International Scientific Research Journal. Vol. 4, pp. 38-55, 2015. https://doi.org/10.18483/IRJSci.74

[41] I.O. Ntwampe, F.B. Waanders, E. Fosso-Kankeu, J.R. Bunt, Reaction dynamics of iron and aluminium salts dosage in AMD using shaking as an alternative technique in the destabilization-hydrolysis process. International Scientific Research Journal. Vol. 1, no. 8, pp. 5-23, 2015. https://doi.org/10.18483/IRJSci.73

[42] E. Fosso-Kankeu, H. Mittal, F. Waanders, I.O. Ntwampe, S.S. Ray, Preparation and characterization of gum karaya hydrogel nanocomposite flocculant for metal ions removal from mine effluents. International Journal of Environmental Science and Technology. Vol. 13, pp. 711-724, 2016. https://doi.org/10.1007/s13762-015-0915-x

[43] E. Fosso-Kankeu, A. Webster, I.O. Ntwampe, F.B. Waanders, Coagulation/flocculation potential of polyaluminium chloride and bentonite clay tested in the removal of methyl red and crystal violet. Arabian Journal for Science and Engineering. DOI 10.1007/s13369-016-2244-x. 2016.

[44] E. Fosso-Kankeu, H. Mittal, S. Marx and S.S. Ray, Hydrogel-based bioflocculants for the removal of organic pollutants from biodiesel wastewater. Journal of Polymer and Environment. DOI 10.1007/s10924-016-0870-8. 2016.

[45] Elvis Fosso-Kankeu. 2019. Nano and Bio-based Technologies for wastewater treatment: Prediction and Control Tools for the dispersion of Pollutants in the Environment. Wiley Scrivener. ISBN: 978-1-119-57709-6. Pp 301-336.

[46] Elvis Fosso-Kankeu. 2019. New Horizons in Wastewaters Management: Emerging Monitoring and Remediation Strategies. Nova Science Publishers. ISBN: 978-1-53615-659-1.

[47] Johannes Cornelius van der Linde, Elvis Fosso-Kankeu, Gerhard Gericke, Frans Waanders, Louise Dreyer, Nico Lemmer. 2019. Flocculant types and operating conditions influencing particles settling rates in feed water used at a coal power plant. Desalination and Water Treatment. 150: 293-300. https://doi.org/10.5004/dwt.2019.23735

[48] E. Fosso-Kankeu, F. Waanders, A.F. Mulaba-Bafubiandi, A.K. Mishra. 2016. Flocculation performances of polymers and nanomaterials for the treatment of industrial wastewaters. In A.K. Mishra (ed). 2016. Smart Materials for Waste Water Applications. Wiley Scrivener. ISBN: 9781119041184. Pp 213 - 235. https://doi.org/10.1002/9781119041214.ch8

[49] John Cluett, Sunny E. Iyuke, Evans T. Musapatika, Sehliselo Ndlovu, Lubinda F. Walubita, Allex E. Alvarez, The treatment of brewery wastewater for reuse: State of the art,2011,(235-247). https://doi.org/10.1016/j.desal.2011.02.035 